\title{
LandGEM Biogas Estimation, Energy Potential and Carbon Footprint Assessments of a Controlled Landfill Site. Case of the Controlled Landfill of Mohammedia-Benslimane, Morocco
}

\author{
Ahlam Idrissi Oukilii ${ }^{*}$, Meriyem Mouloudi ${ }^{2}$,Mostafa Chhiba'
}

1 Faculty of Science and Technology, Laboratory of Radiations Materials and Instrumentations, Hassan First University of Settat, Road to Casablanca Km 3.5, 26000, Settat, Morocco

2 Faculty of Science and Technology, Laboratory of Applied Chemistry and Environment, Hassan First University of Settat, Road to Casablanca Km 3.5, 26000, Settat, Morocco

* Corresponding author's e-mail: ahlamisdrissioukili@yahoo.fr

\begin{abstract}
Landfills throughout the world are contributing to the global warming problem. This is due to the existence of the most important greenhouse gases in landfill gas; namely, methane and carbon dioxide. Methane has a high potential for energy production and by utilizing the proper technology, large amounts of energy can be extracted from it. This paper deals with the estimation of methane emissions from the controlled municipal solid waste landfill of Mohammedia-Benslimane (MB) in Morocco. Methane emissions were calculated using the LandGEM method. In this research, the following parameters were evaluated: the amount of landfilled waste, the characteristics of the landfill and the composition of the landfilled waste, as well as the climatic conditions prevailing in the region. According to the LandGEM model, the total amount of methane generated from approximately $3.663 \mathrm{E}+06 \mathrm{~kg}$ of municipal solid waste that will be buried of in the MB controlled landfill over 20 years, 2012 to 2032 , is $1.76 \mathrm{E}+08 \mathrm{~m}^{3}$. For the year 2020 , the estimated electrical energy production in the landfill is $1.78 \mathrm{E}+07 \mathrm{kWh}$. Regarding the carbon footprint for this landfill, the landfilling of household solid waste at the MB landfill has resulted in a production of about $499,238,000 \mathrm{~kg} \mathrm{CO}_{2} \mathrm{e}$ in 2020 since its opening in 2012, according to the LandGEM model. These huge amounts of greenhouse gas are related to the fact that the waste buried at this landfill is highly organic. By installing an efficient system to capture and flare the biogas generated in this landfill, the management of this landfill is actively contributing to the protection of the environment by mitigating greenhouse gas emissions, particularly methane.
\end{abstract}

Keywords: municipal solid waste, LandGEM, methane, carbon footprint, greenhouse effect, electrical energy.

\section{INTRODUCTION}

In the same way as developing countries, Morocco has experienced a strong growth of the legal population estimated at 33,848,242 inhabitants, with 7,313,806 households (High Commissariat for Planning, RGPH 2014) and a huge industrial boom. Indeed, the improvement in life styles, and changes in production and consumption patterns and the proliferation of peripheral neighborhoods have led to a consequent increase in the volume of household waste produced. The current production of household waste in urban areas in Morocco is 5.38 million tons per year, or an average of
$0.76 \mathrm{~kg}$ per capita per day, and in rural areas 1.47 million tons per year, or an average of $0.28 \mathrm{~kg}$ per capita per day [Saghir et al., 2018]. With population growth, rapid urbanization and changing consumption patterns, the production of household waste in Morocco is increasing. This situation has made the collection, evacuation, disposal and treatment of household and similar waste more difficult. This waste is very often disposed of in uncontrolled landfills [Elmaghnougi et al., 2018], or in black spots and water ways without any treatment or control, which has serious consequences both for public health and the environment as well as for the future of socio-economic 
activities in our country. And considering that the patrimonial management of the vital space, the management of the environment and the sustainable development are part of the current concerns of the State, the creation of the controlled dumps turned out to be a major necessity to face this difficult situation. The rate of controlled landfill that was planned in 2019 is $62.63 \%$, this rate should reach $100 \%$ in 2022 (Ministry of Energy, Mines and Environment). In fact, a controlled landfill, also known as an engineered landfill, is a place designed for the deposit of waste for a specific period of time while avoiding as much as possible the nuisance to the neighborhoods, caused mainly by the emanation of greenhouse gases (methane) [Abbasi, 2018] and the infiltration of leachate [Chofqi et al., 2004]. From the deposition phase, the waste is subjected to degradation processes related to complex biological and physicochemical reactions [Kumar et al., 2017]. Water seeps through and produces leachate and biogas loaded with organic and mineral substances that generate pollution mainly of organic and metallic type, related to the natural biodegradation of the confined waste and with its anthropogenic components that release many toxic substances into the natural environment. The burial and storage of solid household waste must therefore allow not only an efficient management of the waste but also the good management of the discharges. By opting for this approach, it becomes necessary to think of solutions to control and minimize these releases.

Morocco ratified the Kyoto Protocol on February 16, 2005, and organized the twentysecond COP 22 conference in Marrakech, from November 07 to November 18, 2016. One of the objectives of COP22 is to reduce and develop household waste through the construction of controlled landfills, in order to combat climate change due to greenhouse gas emissions. In this context, it is constantly improving environmental projects of which waste management projects are part. These projects focus on the evolution of controlled landfills into Landfill and recovery Centre in order to reduce greenhouses gas emissions. Indeed, the controlled landfill, although essential, cannot be considered as a sustainable solution of waste management, because important emissions of greenhouse gas persist even after their closure. Therefore, for a sustainable management of household waste, the development of material and energy recovery channels is undoubtedly important, and remains the appropriate solution to save raw materials, reduce the amount of waste to be eliminated and thus limit the extent of controlled landfills and the negative impacts on the environment, as well as create new jobs and generate income.

Household waste in Morocco contains 50$70 \%$ organic matter, so landfills in Morocco are one of the sources of biomass. Based on calculations of the energy potential of biomass, it can be deduced that the amount of electricity that can be produced by incinerating household waste in the Rabat region is approximately one hundred gigawatt hours [Naimi et al., 2017].

A recently published research study on the analysis of the economic feasibility and environmental impact of landfill gas on energy technologies in African urban areas (53 countries), showed that converting landfill gas to electricity could reduce global warming potential by $72.2 \%$ and increase acid gas emissions by $8.75 \%$ to $9.00 \%$ in African urban areas in 2012 [Cudjoe et al., 2021]. This study will guide investment and decision-making on the environmental sustainability of energy projects in Africa.

Currently, the choice of waste treatment in the communes of Mohammedia and Benslimane is oriented rather towards burying and flaring of biogas. However, although this management method has the advantage of reducing the negative effects of waste on the environment, it does not allow the potential of this biomass to be exploited in terms of recycling of materials, and alsoin terms of production of an organic amendment by composting and energy production.

The objectives of this study are:

- The use of the LandGEM kinetic model to estimate the amount of methane generated by the anaerobic decomposition of waste buried in the Mohammedia-Benslimane controlled landfill and to make a comparison with the data obtained on this site.

- Assessment of the energy potential of this landfill site

- The contribution of this site to the reduction of the greenhouse effect

\section{MATERIALS AND METHODS}

\section{Presentation of the study area}

The prefecture of Mohammedia covers an area of $180 \mathrm{~km}^{2}$ and is located on the Atlantic 
coast $25 \mathrm{~km}$ north of the city of Casablanca, while the province of Benslimane covers an area of $2,760 \mathrm{~km}^{2}$, it is bounded by Skhirat-Temara to the north, Settat to the south, Khmisset to the east and the Atlantic Ocean to the west.

The controlled landfill of MohammediaBenslimane was commissioned on February 27/2012, after the closure of the unctrolled landfill of Mesbahiat. It has a capacity of 5 million cubic meters $\left(\mathrm{m}^{3}\right)$ of waste and will be operated over a period of 20 years (until 2032). It covers an area of 109 hectares, of which the exploited area is 47 hectares. This landfill is located approximately $8 \mathrm{~km}$ south east of the center of Beni Yakhlef, $17 \mathrm{~km}$ east of the center of Mohammedia, $24 \mathrm{~km}$ south west of the center of Benslimane, and $800 \mathrm{~m}$ from the provincial road RP 3313 precisely to Beni M'ghit Chaâba El Hamra (ECOMED Group). Figure 1 shows the geographical location of the site.

The controlled landfill of MohammediaBenslimane, class I, which has the concept of an anaerobic bioreactor with storage in a controlled cell, is based on an efficient disposal of solid waste to avoid any harm to the environment and human health. Only household and similar wastes, inert wastes and non-hazardous wastes are allowed in the landfill.

The landfill is located on a site designed to accommodate five large landfill cells and five raw leachate ponds. The site also contains a weighbridge to control the admission of waste with their weighing. Its capacity is $60,000 \mathrm{~kg}$ and its uncertainty is $20 \mathrm{~kg}$ per $1,000 \mathrm{~kg}$, this uncertainty is considered negligible.

For the evacuation of the generated biogas, a drainage network in the closed compartments is installed. At present, after 8 years of operation, the first three landfills are completely filled with household and similar waste, while the fourth one is under operation. The landfill is equipped with two flares to burn the biogas generated by the anaerobic decomposition of the waste. The first flare operates continuously

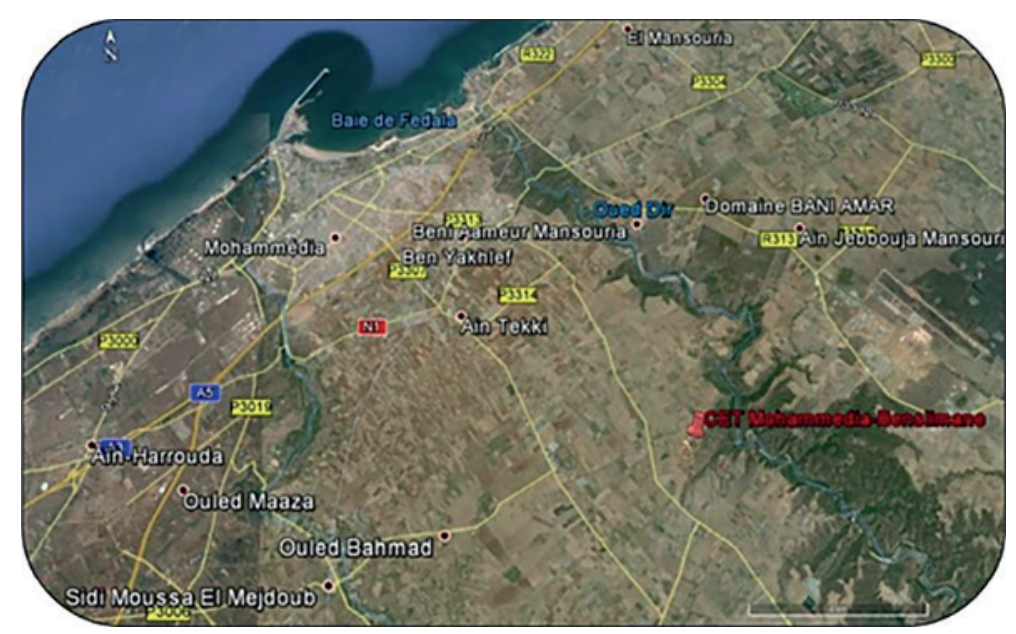

Figure 1. Geographical location of the Mohammedia-Benslimane landfill
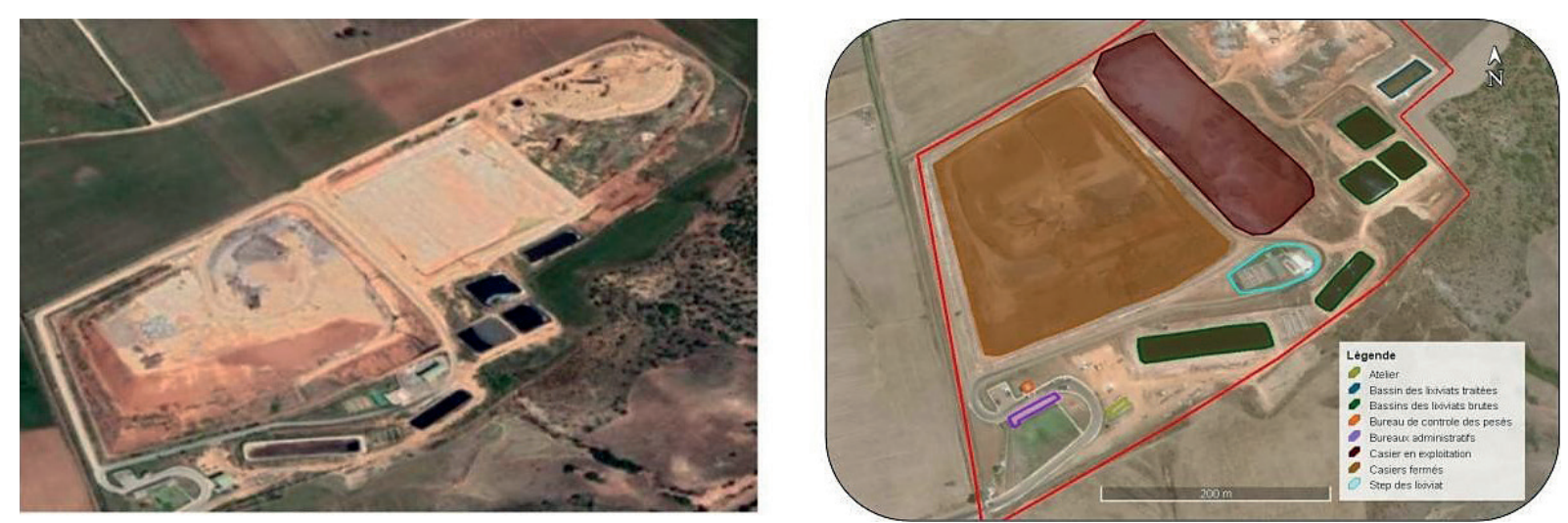

Figure 2. Aerial view of the Mohammedia-Benslimane technical landfill site 


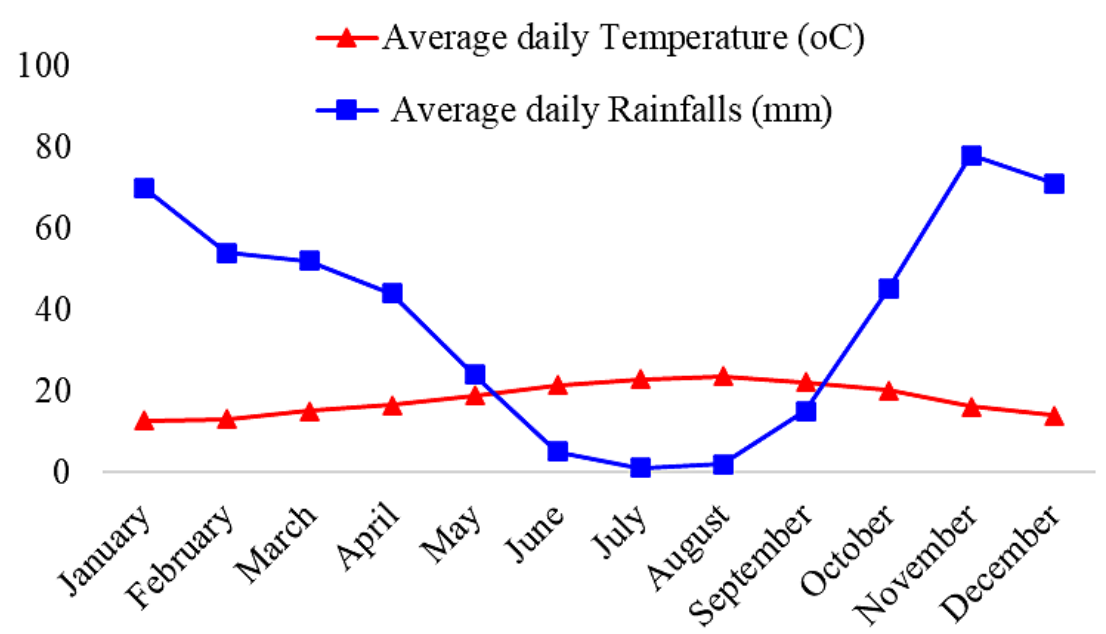

Figure 3. Climate conditions in the Beni Yakhlef region in 2020

(passive), while the second flare operates 3 hours per day (active) and can burn up to 1,000 $\mathrm{m}^{3}$ of methane per hour at a temperature of about $900{ }^{\circ} \mathrm{C}$. The active flare is capable of burning biogas with a methane content between 20 and $70 \%$. The biogas collection system includes a booster that creates a negative suction pressure to draw the collected landfill gas from the landfill waste to the flares.

The biogas flare system has a control panel to operate the flare, display and record data. The flare system also measures the biogas flow rate with a flow meter $\left(\mathrm{Nm}^{3} / \mathrm{h}\right)$ and the gas concentration with a biogas analyzer $\left(\mathrm{CH}_{4}, \mathrm{CO}_{2}, \mathrm{O}_{2}\right.$ and $\mathrm{H}_{2} \mathrm{~S}$ ). Data are recorded every hour to monitor the flow rate and quality of the biogas produced by the anaerobic degradation of the landfilled waste.Figure 2 shows an aerial view of the Mohammedia-Benslimane landfill site.

The proximity to the Atlantic Ocean gives the municipality of Beni Yakhlef, where the Mohammedia-Benslimane controlled landfill site is located, a temperate and humid climate with a mild winter and a summer that is cooled by the ocean breezes. Figure 3 shows the climatic conditions of the Mohammedia-Benslimane controlled landfill site. Over the year, the average temperature at Beni Yakhlef is $18{ }^{\circ} \mathrm{C}$ and the average rainfall is $461 \mathrm{~mm}$.

The technical landfill site ensures two essential missions which are:

- Burying of solid waste

- The treatment of biogas by flaring to mitigate the greenhouse effect caused by the emission of methane.

\section{The nature and quantity of landfill waste}

Since its opening, the site receives household and similar waste, green waste, rubble and sweeping waste from nine local communities of the prefecture of Mohammedia and the province of Benslimane, as well as ordinary industrial waste from various companies in the region (Table 1). The communes of the prefecture of Mohammedia are: the two urban communes (Mohammedia and Ain Arruda), and the four rural communes (Beni Yakhlef, Sidi Moussa El Majdoub, Sidi Moussa Ben Ali and Ech-challalate). As well as the three urban communes of the province of Benslimane: (Benslimane, Bouznika, and El Mansouria).

The quantity of municipal solid waste (MSW) buried in this site from 2012 to 2020 was provided by the ECOMED-Mohammedia group. The amount of MSW from 2021 to 2032 has been extrapolated using the demographic data of the Mohammedia prefecture and the Benslimane province. According to the data from the General Census of Population and Housing (RGPH-20042014), the population of the nine communes increased from 410,832 inhabitants in 2004, to 518,840 inhabitants in 2014 spread over

Table 1. Fraction of different types of waste landfilled (ECOMED Group, 2020)

\begin{tabular}{|l|c|c|}
\hline \multicolumn{1}{|c|}{ Waste category } & $\begin{array}{c}\text { Amount of } \\
\text { waste (tons) }\end{array}$ & $\begin{array}{c}\text { Percentage by } \\
\text { weight (\%) }\end{array}$ \\
\hline Household waste & 162,625 & 78.34 \\
\hline Household waste & 2,564 & 1.24 \\
\hline OM-Soil-Gravel mixture & 7,937 & 3.82 \\
\hline Gravel & 570 & 0.27 \\
\hline Ordinary industrial waste & 33,901 & 16.33 \\
\hline
\end{tabular}


Table 2. Evaluation of the population of the communes of Mohammedia - Benslimane (RGPH-2004-2014)

\begin{tabular}{|l|c|c|c|c|}
\hline \multirow{2}{*}{ Communes } & \multicolumn{2}{|c|}{2004} & \multicolumn{2}{c|}{2014} \\
\cline { 2 - 5 } & Population & Households & Population & Households \\
\hline Mohammedia & 188,619 & 39,154 & 208,612 & 49,974 \\
\hline Ain Harrouda & 41,853 & 8,417 & 62,420 & 15,143 \\
\hline Beni Yakhlef & 33,112 & 6,681 & 48,338 & 10,827 \\
\hline Ech-Challalate & 40,311 & 7,970 & 53,503 & 12,840 \\
\hline Sidi Moussa Al Majdoub & 12,412 & 2,502 & 20,330 & 4,917 \\
\hline Sidi Moussa Ben Ali & 9,368 & 1,666 & 11,445 & 2,650 \\
\hline Benslimane & 45,195 & 9,430 & 57,101 & 13,092 \\
\hline Bouznika & 27,028 & 5,305 & 37,238 & 8,488 \\
\hline Manssouria & 12,934 & 2,787 & 19,853 & 4,842 \\
\hline Total & 410,832 & 83,912 & 518,840 & 122,773 \\
\hline
\end{tabular}

approximately 122,773 households, i.e., an annual growth rate of $2.36 \%$ (Table 2). Using the available data for the population and the amount of waste landfilled in the site during the two years 2019 and 2020, the specific daily waste generation regarding this area is $0.75 \mathrm{~kg} / \mathrm{capita} / \mathrm{day}$.

The landfill of Mohammedia-Benslimane, receives the waste during the opening hours starting from 12 am until $16 \mathrm{pm}$. The waste stored in the Mohammedia-Benslimane interprovincial controlled landfill is regularly monitored, weighed and the data is archived (500 tons/day). This process has started since the opening of the landfill in 2012. In this study, we used the available data from 2012 to 2020 (ECOMED Group), and then interpolated to 2032, the year the landfill is expected to close.

With data from the RGPH population censuses, from 2004 and 2014, it is possible to elaborate the population growth and/or decrease rate of each community, using geometric progression. The average of per capita waste

Table 3. Index of municipal waste generation per capita

\begin{tabular}{|l|c|c|}
\hline \multirow{2}{*}{\multicolumn{1}{c|}{ Communes }} & \multicolumn{2}{c|}{$\begin{array}{c}\text { Per Capita Generation } \\
\text { Index } \\
\text { (kg/inhabitant/day) }\end{array}$} \\
\cline { 2 - 3 } & Year 2019 & Year 2020 \\
\hline Mohammedia & 0.997 & 0.936 \\
\hline Ain Harrouda & 0.545 & 0.501 \\
\hline Beni Yakhlef & 0.701 & 0.689 \\
\hline Ech-Challalate & 0.341 & 0.443 \\
\hline Sidi Moussa Al Majdoub & 0.277 & 0.292 \\
\hline Sidi Moussa Ben Ali & 0.150 & 0.172 \\
\hline Benslimane & 0.760 & 0.728 \\
\hline Bouznika & 1.086 & 1.047 \\
\hline Manssouria & 0.954 & 0.903 \\
\hline
\end{tabular}

generation was estimated in the period 20192020 (Table 3).

Municipal solid waste produced annually in the future years by each community is simply calculated by multiplying the estimated population amount by the per capita waste production in this region (Table 3). The final amount disposed at Mohammedia-Benslimane Landfill was estimated by the sum of the annual waste produced by each community.

Table 4. Amount of waste landfilled from 2012 to 2020 and the projection to 2031

\begin{tabular}{|c|c|c|}
\hline \multirow{2}{*}{ Year } & Waste Acceptance & Waste-In-Place \\
\cline { 2 - 3 } & (tons/year) & (tons) \\
\hline 2012 & 151,501 & 0 \\
\hline 2013 & 168,008 & 151,501 \\
\hline 2014 & 195,617 & 319,509 \\
\hline 2015 & 182,360 & 515,126 \\
\hline 2016 & 179,862 & 697,486 \\
\hline 2017 & 169,854 & 877,348 \\
\hline 2018 & 178,033 & $1,047,202$ \\
\hline 2019 & 182,983 & $1,225,235$ \\
\hline 2020 & 173,126 & $1,408,218$ \\
\hline $2021^{*}$ & 169,288 & $1,581,344$ \\
\hline $2022^{*}$ & 173,201 & $1,750,632$ \\
\hline $2023^{*}$ & 177,236 & $1,923,833$ \\
\hline $2024^{*}$ & 181,395 & $2,101,069$ \\
\hline $2025^{*}$ & 185,683 & $2,282,464$ \\
\hline $2026^{*}$ & 187,540 & $2,468,147$ \\
\hline $2027^{*}$ & 192,007 & $2,655,687$ \\
\hline $2028^{*}$ & 196,614 & $2,847,694$ \\
\hline $2029^{*}$ & 201,366 & $3,044,308$ \\
\hline $2030^{*}$ & 206,269 & $3,245,674$ \\
\hline $2031^{*}$ & 211,328 & $3,451,943$ \\
\hline $2032^{*}$ & 0 & $3,663,271$ \\
\hline
\end{tabular}

* Projected value 


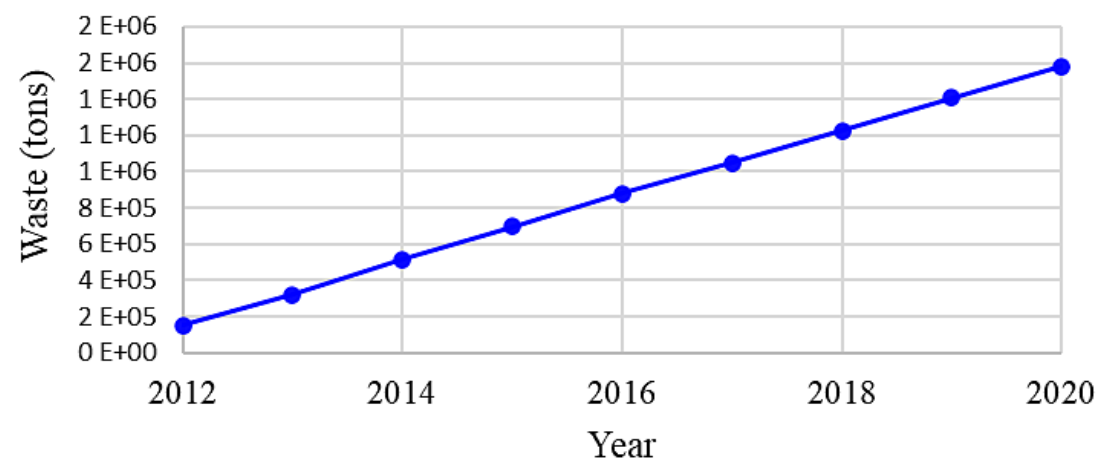

Figure 4. Evolution of landfilled waste by year

Table 4 shows the annual amount of waste landfilled in tons at the Mohammedia-Benslimane landfill from the year 2012 until the year 2020 , with the projection made for the 2021 to 2031.

The amount of waste received has increased from approximately 151,501 tons in 2012 to 173,126 tons in 2020. Figure 4 illustrates the evolution of the quantity of waste buried in tons in the site since its opening in 2012. It can be seen that there is a good correlation between the amount of waste landfilled and the year.

Figure 5 shows the monthly amount of waste landfilled for each commune in 2020. It was observed that the urban commune of Mohammedia is the largest producer of waste compared to the other communes. The commune of Mohammedia has the highest population density in this area. It could be observed again, that the average of daily specific waste production concerning the urban communes $(0.85 \mathrm{~kg} /$ inhabitant/day) is higher than that of the rural communes $(0.38 \mathrm{~kg} /$ inhabitant/day).

\section{Estimating the carbon footprint of the Mohammedia-Benslimane landfill}

Although greenhouse gas emissions are much discussed in developed countries around the world, they are of little concern in developing countries. Carbon dioxide and methane from biodegradation of waste are the only gases considered in this study. Global warming potential (GWP) of 1 and 21 were considered for $\mathrm{CO}_{2}$ and $\mathrm{CH}_{4}$ respectively [Kumar et al., 2017, Noor et al., 2013]. The carbon footprint (CF) of this landfill was evaluated from the two majority components $\left(\mathrm{CH}_{4}\right.$ and $\left.\mathrm{CO}_{2}\right)$ of the biogas produced and is given by Eq. (1) [Haro et al., 2019]. These biogas components are evaluated using the LandGEM V3.03 (June 2020) first order kinetic model provided by the US Environmental Protection Agency (US.EPA).

$$
\begin{aligned}
C F & =\left(Q_{\mathrm{CH}_{4}} * \rho_{\mathrm{CH}_{4}} * G W P_{\mathrm{CH}_{4}}\right)+ \\
& +\left(Q_{\mathrm{CO}_{2}} * \rho_{\mathrm{CO}_{2}} * G W P_{\mathrm{CO}_{2}}\right)
\end{aligned}
$$



Figure 5. Monthly waste generation in the study area for the year 2020 
were:

- $C F$ : Amount of GHGs in tons of carbon dioxide equivalent $\left(\mathrm{tCO}_{2} \mathrm{eq}\right)$.

- $Q_{\mathrm{CH}_{4}}$ : Amount of methane emitted into the atmosphere in ( $\mathrm{m}^{3} /$ year).

- $\rho_{\mathrm{CH}_{4}}$ : Density of methane $\left(0.667 \mathrm{~kg} / \mathrm{m}^{3}\right)$.

- $G_{W P} \mathrm{CH}_{4}$ : Global warming potential of methane $(\mathrm{GWP}=21)$.

- $Q_{\mathrm{CO}_{2}}$ : Amount of carbon dioxide emitted into the atmosphere in $\left(\mathrm{m}^{3} /\right.$ year $)$.

- $\rho_{\mathrm{CO}_{2}}$ : Density of carbon dioxide $\left(1.87 \mathrm{~kg} / \mathrm{m}^{3}\right)$.

- $\mathrm{GWP}_{\mathrm{CO}_{2}}$ : Global warming potential of carbon dioxide $(\mathrm{GWP}=1)$.

\section{Estimation of the electrical energy generated by the MB landfill}

The production of electrical energy from methane produced by a controlled landfill is a common application and its use is very beneficial. Electricity can be generated by burning methane in a generator set or gas turbine. The potential for generating electrical energy from landfill methane recovery was estimated using Eq. (2) [Ayodele et al., 2017]:

$$
E_{\text {elc }}=\frac{0.9 * Q_{C_{4}} * L H V_{C H_{4}} * \eta * \lambda}{3.6}
$$

The is the amount of methane gas emitted in $\mathrm{m}^{3}$ from the landfills during the particular year, is the Lower Heating Value of methane and usually taken as 35.8 MJ per $\mathrm{m}^{3}$ [Saghir et al., 2018], $\eta$ is the electrical conversion efficiency for the internal combustion engine and usually taken as $35 \%$ [Saghir et al., 2018], $\lambda$ is the collection efficiency of methane from landfills and usually taken as $75 \%, 0.9$ is the empirical coefficient and 3.6 is the conversion factor from $\mathrm{MJ}$ to $\mathrm{kWh}$ (Low calorific value : $\mathrm{LCV}_{\mathrm{CH} 4}=9.94 \mathrm{kWh} / \mathrm{m}^{3}$ at To $=273 \mathrm{~K}$ and $\mathrm{Po}=1 \mathrm{~atm})$.

\section{Landfill gas emissions model (LandGEM)}

\section{Description of the LandGEM model}

LandGEM is a commonly used model to estimate the amount of landfill gas generation. This model is developed by the Control Technology Center of the American Environmental Protection Agency (US.EPA) for the prediction of gaseous pollutant generation in solid waste landfills. It considers (i) the quantities and characteristics of the landfilled waste over several consecutive years, (ii) the characteristics of the biogas produced and (iii) the meteorological conditions in the study area. It allows the prediction of $\mathrm{CH}_{4}$ and $\mathrm{CO}_{2}$ generation up to 140 years from the first-order decomposition equation [EPA USA, 2008]. The $\mathrm{CH}_{4}$ generation Eq. (3) considers increments of one tenth $(1 / 10)$ of a year in order to increase the accuracy of the estimation process.

$$
Q_{C H_{4}}=\sum_{i=1}^{n} \sum_{j=0,1}^{1} k * L_{0} *\left(\frac{M_{i}}{10}\right) * e^{-k t_{i, j}}
$$

were:

- $Q_{\mathrm{CH}_{4}}$ : annual methane generation in the year of the calculation $\left(\mathrm{m}^{3} / \mathrm{year}\right)$

- $n$ : define as (year of the calculation) - (initial year of waste acceptance)

- $i:$ is the one -year time increment

- $j$ : is the 0.1 year time increment

- $k$ : methane generation rate $\left(\right.$ year $\left.^{-1}\right)$

- $L_{0}$ : potential methane production capacity $\left(\mathrm{m}^{3} / \mathrm{Mg}\right)$

- $M_{i}$ : mass of waste accepted in the $\mathrm{i}^{\text {th }}$ year $(\mathrm{Mg})$

- $t_{i, j}$ : age of the $j^{\text {th }}$ section of waste mass Mi accepted in the $\mathrm{i}^{\text {th }}$ year (decimal years)

To conduct our study, the required inputs for estimating the amount of generated landfill gas are the landfill opening year, the landfill closure year, the annual waste acceptance rates from the opening to the closure year, the potential methane production capacity $\mathrm{L}_{0}$, the methane generation rate $\mathrm{k}$, the methane proportion in the biogas and Nom Methane Organic Compound concentration (NMOC).

\section{LandGEM Model Parameters}

In the LandGEM model the degradable organic carbon (DOC) is entered into Eq. (4) to yield the methane generation potential $\left(\mathrm{L}_{0}\right)$ [Ayodele et al., 2017, Pillai et al., 2018]:

$$
L_{0}=M C F \times D O C \times D O C_{f} \times F \times \frac{16}{12}
$$

where: $L_{0}$ is the methane generation potential ( $\mathrm{kg} / \mathrm{ton}), \mathrm{MCF}$ is the methane correction factor $(\mathrm{MCF}=1$ for sanitary landfills, 0.4 -0.8 for waste dumps); DOC is the degradable organic yielded on of methane in landfill gas ( 0.5 default), and $16 / 12$ is the stoichiometric factor (the ratio of the molecular mass of methane to carbon). 
Table 5. Fraction of different solid waste components

\begin{tabular}{|c|c|c|c|c|}
\hline Waste type & A & B & C & D \\
\hline Pourcentage $(w t \%)$ & 19.4 & 3.1 & 75.9 & 1.6 \\
\hline
\end{tabular}

The degradable organic carbon (DOC) is simply calculated using Eq. (5) and the waste characterization data for the Mohammedia-Benslimane landfill (Table 5).

$$
\begin{gathered}
D O C=(0.40 \times A)+(0.17 \times B)+ \\
+(0.15 \times C)+(0.30 \times D)
\end{gathered}
$$

A fraction of municipal solid waste (MSW) that is paper and textiles, waste $B$ fraction of MSW that is garden or park waste, $C$ fraction of MSW that is food waste, and $D$ fraction of MSW that is wood or straw waste.

For the estimation of the methane generation potential [according to Eq. (4)] the following values have been applied: $\mathrm{MCF}=1$ (managed landfill); $\mathrm{DOC}=0.20 \mathrm{kgC} / \mathrm{kg}$-waste; $\mathrm{DOC}_{\mathrm{f}}=0.5$ and $\mathrm{F}=0.6$ (measured in-situ). Hence, the methane formation potential $\mathrm{L}_{0}=120 \mathrm{~m}^{3} /$ ton (density of methane $=0.667 \mathrm{~kg} / \mathrm{m}^{3}$ ).

In this study, a theoretical $\mathrm{k}$ value was calculated using the composition of the disposed waste (Table 4). The $\mathrm{k}$ value of the controlled landfill of Mohammedia-Benslimane can be calculated from a weighted average (wt. fraction ${ }_{\mathrm{i}}$ ) of the $\mathrm{k}$ of each biodegradable component $\left(\mathrm{k}_{\mathrm{i}}\right)$ as described in Eq. (6) as follows [Park et al., 2017, Pillai et al., 2018]:

$$
k=\sum_{i=1}^{n}\left(k_{i} *\left(\text { wt. } \text { fraction }_{i}\right)\right)
$$

The IPCC (Intergovernmental Panel on Climate Change) lists the $\mathrm{k}$ values for food, garden/park, paper/textiles and wood/straw wastes as 0.06 year $^{-1}, 0.05$ year $^{-1}, 0.04$ year $^{-1}$, and 0.02 year $^{-1}$ respectively. Others wastes, non-biodegradables, were not incorporated into this weighted average. Using the defaults values and the Eq. (6), the $\mathrm{k}$ value was calculated as 0.055 year-1 $^{-1}$ for this controlled landfill site.

\section{RESULTS AND DISCUSSION}

The results of this study are presented in four parts: (a) characterization of the biogas produced by the waste in this landfill, (b) estimation of the biogas produced using the LandGEM model, (c) estimation of the energy potential, and (d) estimation of the global warming potential reduction.

\section{Biogas characterization and evaluation of the methanogenic potential of the CET}

The controlled landfill of MohammediaBenslimane, Morocco, receives a waste flow of about 500 tons per day, composed of biodegradable and non-biodegradable fractions. The biodegradable organic waste generates, through anaerobic biological decomposition, a biogas mainly composed of carbon dioxide and methane which are greenhouse gases. In-situ analyses of biogas have revealed an average methane content of around $60 \%$ by volume. Table 5 showsthe results of in-situ measurements in 2020 for $\mathrm{CH}_{4}(\%$ by volume), $\mathrm{CO}_{2}$ (\% by volume) and $\mathrm{H}_{2} \mathrm{~S}$ (ppm), the biogas volume flow rate $\left(\mathrm{Nm}^{3} / \mathrm{h}\right)$, the biogas pressure (mbar) and the temperature of the biogas combustion reaction in the closed active flare. For biogas recovery, the open fraction of the extractor valve is only $22.45 \%$. The biogas collection is done by a network of horizontal wells.

It should be noted that the values grouped in the table 6 are the averages of all the measurementscarried out at the level of the closed active flare inlet and the horizontal capture well present on the cells. Therefore, they correspond to the overall flow of the landfill site. (In-situ monitoring for 76 days in the period 02/2020-05/2020).

The results obtained show constant values of stable proportions of $\mathrm{CH}_{4}$ and $\mathrm{CO}_{2}$ of $59.59 \%$ and $38.97 \%$ respectively were obtained (Fig. 6). These percentages are very close to the average values found in the literature during methanogenesis in anaerobic fermentations: $60 \% \mathrm{CH}_{4}$ and $40 \% \mathrm{CO}_{2}$. Very similar values were obtained for the La Gabarre landfill in Guadeloupe [Plocoste et al., 2016].

Table 6. In-situ measurement results for methane, carbon dioxide, oxygen and hydrogen sulfide, biogas pressure and flow, and temperature of the closed flare system in 2020 (given by the landfill operator)

\begin{tabular}{|c|c|c|c|c|c|c|}
\hline $\mathrm{CH}_{4}(\mathrm{Vol} \%)$ & $\mathrm{CO}_{2}(\mathrm{Vol} \%)$ & $\mathrm{O}_{2}(\mathrm{Vol} \%)$ & $\mathrm{H}_{2} \mathrm{~S}(\mathrm{ppm})$ & Biogas flow $\left(\mathrm{Nm}^{3} / \mathrm{h}\right)$ & Pressure $(\mathrm{mbar})$ & $\mathrm{T}\left(\right.$ The closed flare system) $\left({ }^{\circ} \mathrm{C}\right)$ \\
\hline 59.59 & 38.97 & 0.13 & 1050.4 & 326 & 250 & 1005.5 \\
\hline
\end{tabular}




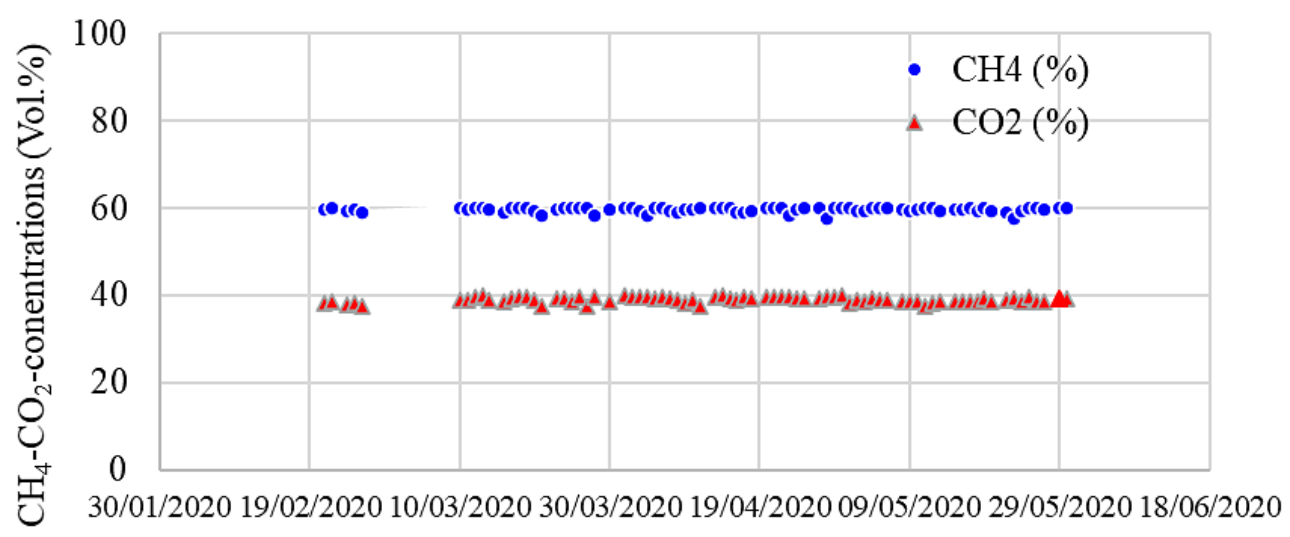

Time

Figure 6. Methane and carbon dioxide concentrations in the gas of the MB landfill site $(21 / 02 / 2020$ to $30 / 05 / 2020)$

The $\mathrm{CH}_{4} / \mathrm{CO}_{2}$ ratio close to 1.5 and a very low amount of oxygen $\left(\mathrm{O}_{2}<1 \%\right)$, suggests that the landfilled waste is in an advanced state of biodegradation (methanogenesis phase). This result indicates that this landfill of Mohammedia-Benslimane has a great capacity to produce methane, which can be energetically valorized (renewable energy). The quantity of hydrogen sulfide $\left(\mathrm{H}_{2} \mathrm{~S}\right)$ found on the landfill site can be explained by the presence of high levels of food waste.

From the flow and the composition of the biogas (Table 6), we can easily calculate the quantity of biogas generated in 2020. This quantity is given by Eq. (7):

$$
\begin{gathered}
Q_{\text {biogas }}=\frac{326}{(1+0.250)} * 24 * \\
* 365 * \frac{1}{0.2245}=10,176,428 \mathrm{~m}^{3}
\end{gathered}
$$

Therefore, in 2020, the annual biogas production is $10,176,428 \mathrm{~m}^{3}$. At a methane (respectively carbon dioxide) content of 59,59\% (respectively $38,97 \%$ ), the annual methane (respectively carbon dioxide) production is reduced to $6,064,133 \mathrm{~m}^{3}$ $\left(3,965,754 \mathrm{~m}^{3}\right.$ respectively).

\section{The results obtained by the LandGEM model}

In Table 7, we have introduced all the data concerning the controlled landfill of Mohammedia- Benslimane and the parameters necessary for the application of the LandGEM model.

Figures $7 \mathrm{a}$ and $7 \mathrm{~b}$ illustrates the annual landfill gas emissions from Mohammedia-Benslimane controlled landfill from 2012 to 2152 .
For the first year of waste deposition in 2012, the model assumes no biogas production. Indeed, the research shows that the methanogenesis stage starts at least 6 months after the waste is deposited. The degradation of the waste depends on several factors: type of waste, moisture in the waste, climatic conditions and the materials covering the waste. To simplify the calculations, the LandGEM kinetic simulation model does not take into account all these parameters to establish the beginning of methanogenesis and considers that after one year, all the criteria are met for the beginning of this stage. According to Figure $7 \mathrm{a}$, we see that it contains two intervals:

Table 7. Parameters for the LandGEM model

\begin{tabular}{|l|c|}
\hline \multicolumn{2}{|c|}{ Landfill characteristics } \\
\hline Landfill open year & 2012 \\
\hline Landfill Closure Year (with 80-year limit) & 2032 \\
\hline Actual Closure Year (without limit) & 2032 \\
\hline Have model calculate closure year? & No \\
\hline Waste Design Capacity (mega grams) & $3,542,350$ \\
\hline \multicolumn{2}{|c|}{ Model parameters } \\
\hline Methane generation rate, k (per year) \\
\hline $\begin{array}{l}\text { Potential methane generation capacity, } \\
\text { I (m } 3 \text { methane /mg waste) }\end{array}$ \\
\hline Nmoc concentration (ppmv as hexane) & 0.055 \\
\hline Methane content (\%) & 4,000 \\
\hline \multicolumn{2}{|c|}{ Gallutants selected } \\
\hline Gas/pollutant \# 1 & Total landfill gas \\
\hline Gas/pollutant \# 2 & Methane \\
\hline Gas/pollutant \# 3 & Carbon dioxide \\
\hline Gas/pollutant \# 4 & NMOC \\
\hline
\end{tabular}






b)

Mega grams Per Year

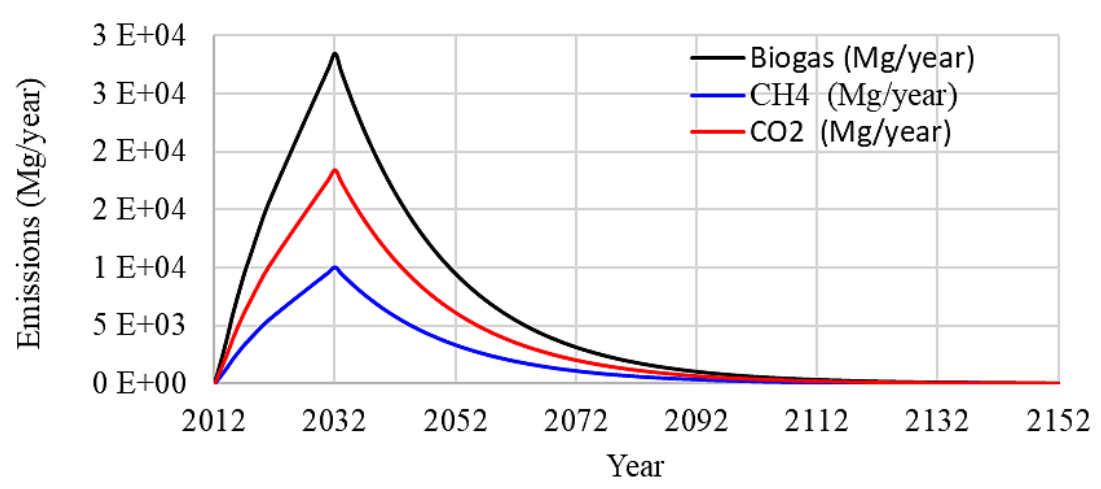

Figure 7. a) Annual estimate of the volume of biogas ( $\mathrm{m}^{3} / \mathrm{year}$ ) of Mohammedia-Benslimane controlled landfill; b) Annual estimate of the quantity of biogas (Mg/year) of Mohammedia-Benslimane controlled landfill

- If $2012 \leq t \leq 2032$ the quantity of biogas increases linearly with the years to reach a maximum value of $2.51 \times 10^{7} \mathrm{~m}^{3} /$ year $(28,450.77$ $\mathrm{Mg}$ ). The maximum estimated quantities of $\mathrm{CH}_{4}$ and $\mathrm{CO}_{2}$ produced are equal to $1.51 \times 10^{7}$ $\mathrm{m}^{3} /$ year $(10,056.20 \mathrm{Mg})$ and $1.00 \times 10^{7} \mathrm{~m}^{3} /$ year $(18,394.56 \mathrm{Mg})$ respectively.

- If $t>2032$ the quantity of biogas generation will decrease exponentially after the landfill closure parallel to the decrease of the amount of decomposable matter in the landfill.

The ratio between the annual biogas production estimated by the LandGEM model and that calculated from the parameters measured in 2020 is calculated by Eq. (8):

$$
\begin{aligned}
R & =\frac{Q_{\text {Biogas-LandGEM }}}{Q_{\text {Biogas-Measurements }}}= \\
& =\frac{1.261 \times 10^{7}}{1.018 \times 10^{7}}=1.24
\end{aligned}
$$

were:
- QBiogas-LandGEM : mean flow of biogas estimated by LandGEM model ( $\mathrm{m}^{3} /$ year)

- $Q_{\text {Biogas-Measurements }}$ : mean flow of biogas determinated from field measurements ( $\mathrm{m}^{3} /$ year)

The landfill gas collection system efficiency defined as the ratio of the collected landfill gas quantity relative to the LandGEM estimated LFG production. From these results, it can be concluded that the biogas recovery efficiency is $81 \%$ of the landfill for the year 2020 . This value is good if considering the EPA regulations for biogas collection and recovery networks, when the recuperation rate of biogas production is defined as being between 75 and $85 \%$.

Several factors can explain this result:

- the biogas recovery area (the three closed cells) is well sealed due to the good coverageof this area by the active ( $2 \mathrm{~mm}$ well protected geomembrane) and passive barriers (clay with a very low permeability of $10^{-9}-10^{-8} \mathrm{~m} / \mathrm{s}$ ).

- the installation of three horizontal well networks under the waste (every 12 meters of waste height there is a collection network) for biogas recovery. 
Despite the construction cost of these horizontal well networks is higher, they have a higher landfill gas collection rate [Fei et al., 2019].

\section{Estimation of the energy potential Mohammedia-Benslimane landfill}

From Eq. (7), we can calculate the annual estimation of electrical energy production by the

Table 8. Annual estimate of electrical energy production by the controlled landfill of Mohammedia-Benslimane

\begin{tabular}{|c|c|c|}
\hline Year & $\begin{array}{c}\text { Annual estimate of the } \\
\text { volume of methane } \\
\text { produced by the landfill } \\
\mathrm{CH}_{4}\left(\mathrm{Mm}^{3} / \text { year }\right)\end{array}$ & $\begin{array}{c}\text { Annual estimate of } \\
\text { electrical energy } \\
\text { production } \\
\mathrm{E}_{\text {elc }}\end{array}$ \\
\hline 2012 & 0.000 & 0.000 \\
\hline 2013 & 0.976 & 2.291 \\
\hline 2014 & 2.005 & 4.709 \\
\hline 2015 & 3.158 & 7.415 \\
\hline 2016 & 4.163 & 9.776 \\
\hline 2017 & 5.098 & 11.973 \\
\hline 2018 & 5.919 & 13.900 \\
\hline 2019 & 6.749 & 15.849 \\
\hline 2020 & 7.566 & 17.768 \\
\hline 2021 & 8.276 & 19.435 \\
\hline 2022 & 8.923 & 20.955 \\
\hline 2023 & 9.561 & 22.452 \\
\hline 2024 & 10.191 & 23.931 \\
\hline 2025 & 10.813 & 25.393 \\
\hline 2026 & 11.430 & 26.842 \\
\hline 2027 & 12.026 & 28.242 \\
\hline 2028 & 12.619 & 29.634 \\
\hline 2029 & 13.210 & 31.021 \\
\hline 2030 & 13.800 & 32.406 \\
\hline 2031 & 14.390 & 33.791 \\
\hline 2032 & 14.980 & \\
\hline
\end{tabular}

Mohammedia-Benslimane controlled landfill. The results of the calculations are collected in Table 8.

From these results gathered in Table 8, we can plot the evolution of the estimated annual production of electrical energy for the landfill of Mohammedia-Benslimane from 2012 to 2032 (Fig. 8).

From this result, it is observed that the estimation of electrical energy production increases with the growth of the amount of methane generated from the controlled landfill. For the year 2032, the estimate of electrical energy production in the landfill will be $35.2 \mathrm{GWh}$.

\section{Carbon footprint of Mohammedia- Benslimane landfill}

Figure 9 shows the evolution of the carbon footprint (CF) over the years of the Mohammedia-Benslimane landfill. The model assumes that there is no biogas production in the first year (2012) of landfilling. The anaerobic fermentation had not yet started. Therefore, biogas production starts in 2013. If the landfill was not equipped with a capture and flare system the contribution to greenhouse gas emissions would have been 115,511 tons $\mathrm{CO}_{2} \mathrm{e}, 164,945$ tons $\mathrm{CO}_{2} \mathrm{e}, 210,945$ tons $\mathrm{CO}_{2}$ e and 210,497 tons $\mathrm{CO}_{2}$ e in 2020, 2025, 2030 respectively and would reach a maximum value of 228,505 tons $\mathrm{CO}_{2} \mathrm{e}$ in 2032. This significant contribution to the greenhouse effect is explained by the high organic content of the waste buried in the landfill and the meteorological conditions. After 2032, the contribution will decrease exponentially and will reach zero after 2152, even though more than 100 years after its closure, the landfill will still contribute to greenhouse gas emissions.

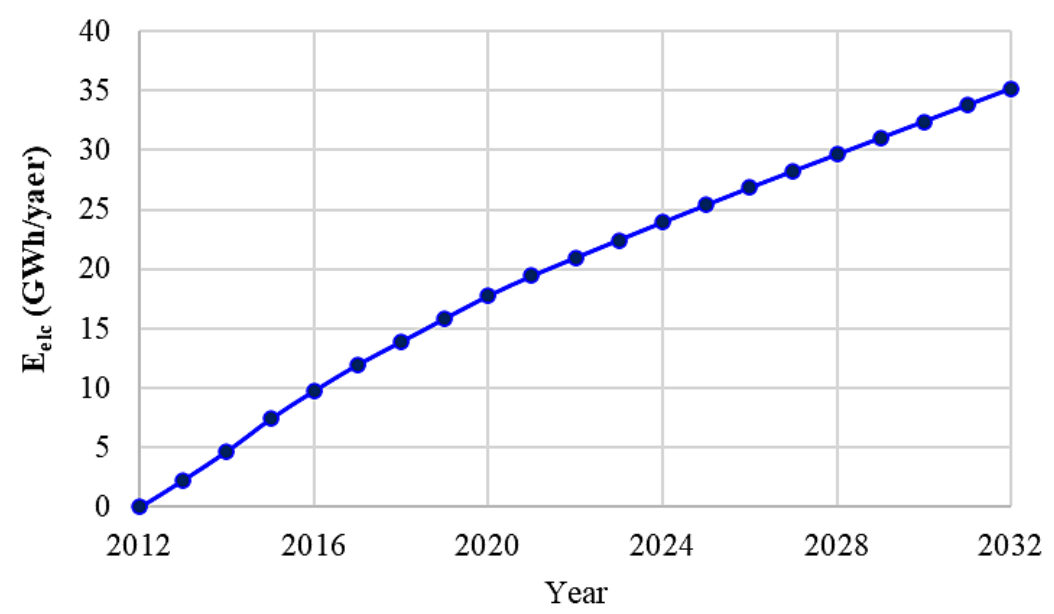

Figure 8. Estimate of the electrical energy generated by the landfill of Mohammedia-Benslimane 


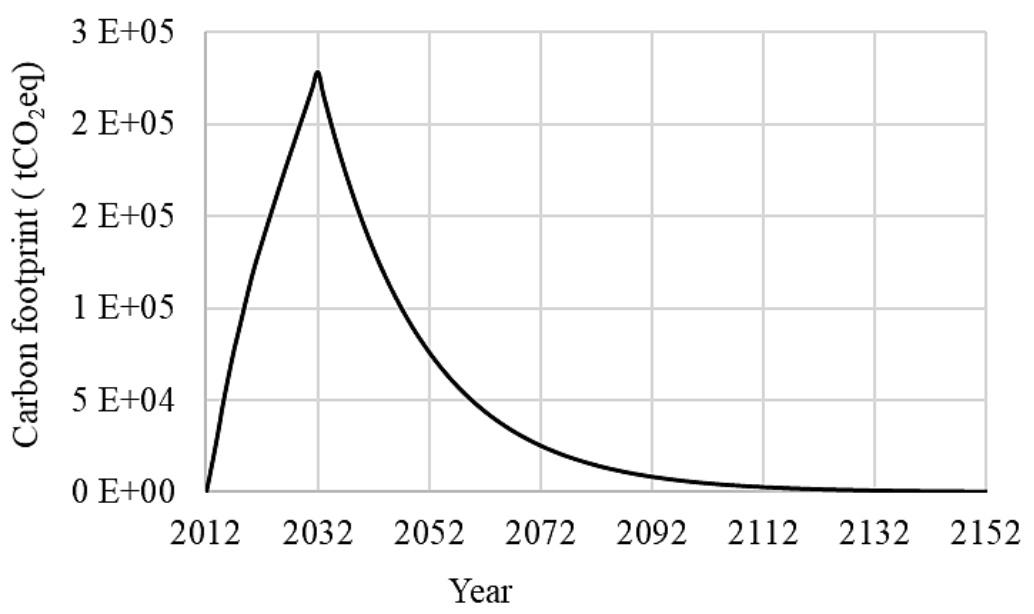

Figure 9. Annual estimate of the quantity of carbon footprint (Mg/year) of Mohammedia-Benslimane landfill

Landfill biogas recovery projects can decrease emissions of greenhouse gases. In the calculation of greenhouse gas reduction by landfill gas recovery we only considered the amount of $\mathrm{CH}_{4}$ destroyed. Using a global warming potential (GWP) of 21 for methane and estimating that $80 \%$ of methane can be captured through the landfill gas collection system and destroyed in flares, with methane reduction efficiency of $90 \%$ in closed flare [Tayyeba et al., 2011, Lattanzi et al., 2020], it is possible to observe the difference between the amount of carbon emitted without the installation of flares and the installation of closed flares (Table 9 and Figure 10).

Considering landfill emissions without any use or destruction of methane, there would be a total of $211,180 \mathrm{Mg}$ of carbon equivalent being generated at the peak of gas production. Against with the closed flare system, it is possible to observe a $72 \%$ reduction in $\mathrm{CO}_{2}$ e emission.

The total emission reductions achievable from the landfill gas recovery during the 20 -year Period, 2012 through 2032, are $1.78 \times 10^{6} \mathrm{Mg}$ of $\mathrm{CO}_{2}$ e (Fig. 11).

By installing a very efficient system for capturing and flaring the biogas generated in the controlled landfill of Mohammedia-Benslimane, the managers of this site will actively contribute to the protection of the environment by mitigating greenhouse gas emissions, particularly methane, with an overall reduction of $1.78 \mathrm{E}+06 \mathrm{tCO}_{2} \mathrm{e}$, in 2032, when the site will close.

\section{CONCLUSIONS}

In this study, the methane generation capacity $\left(\mathrm{L}_{0}\right)$ and methane generation rate $(\mathrm{k})$ were determined for the Mohammedia-Benslimane controlled landfill and methane gas emissions were estimated by using the landGEM 3.03 model. The use of methane produced by the anaerobic decomposition of municipal solid waste in the Mohammedia-Benslimane controlled landfill is a good approach to generating electrical energy and protecting the environment through

Table 9. Estimated methane generated annually from 2012 to 2032, with respective $\mathrm{CO}_{2} \mathrm{e}$ values in two scenarios (without flare and with the closed flare)

\begin{tabular}{|c|c|c|c|}
\hline Year & $\begin{array}{c}\text { Methane } \\
\text { (Mg/year) }\end{array}$ & $\begin{array}{c}\mathrm{CO}_{2} \mathrm{e} \\
\text { (Mg/year) } \\
\text { without flare }\end{array}$ & $\begin{array}{c}\mathrm{CO}_{2} \mathrm{e} \\
\text { (Mg/year)with the } \\
\text { closed flare }\end{array}$ \\
\hline 2012 & 0 & 0 & 0 \\
\hline 2013 & 651 & 13,668 & 9,841 \\
\hline 2014 & 1,338 & 28,094 & 20,228 \\
\hline 2015 & 2,107 & 44,239 & 31,852 \\
\hline 2016 & 2,777 & 58,323 & 41,993 \\
\hline 2017 & 3,401 & 71,429 & 51,429 \\
\hline 2018 & 3,949 & 82,930 & 59,710 \\
\hline 2019 & 4,503 & 94,554 & 68,079 \\
\hline 2020 & 5,048 & 106,002 & 76,321 \\
\hline 2021 & 5,521 & 115,948 & 83,483 \\
\hline 2022 & 5,949 & 124,933 & 89,952 \\
\hline 2023 & 6,372 & 133,811 & 96,344 \\
\hline 2024 & 6,790 & 142,597 & 102,670 \\
\hline 2025 & 7,205 & 151,305 & 108,939 \\
\hline 2026 & 7,617 & 159,949 & 115,163 \\
\hline 2027 & 8,026 & 168,542 & 121,350 \\
\hline 2028 & 8,433 & 177,097 & 127,510 \\
\hline 2029 & 8,839 & 185,626 & 133,651 \\
\hline 2030 & 9,245 & 194,142 & 139,782 \\
\hline 2031 & 9,650 & 202,657 & 145,913 \\
\hline 2032 & 10,056 & 211,180 & 152,050 \\
\hline
\end{tabular}




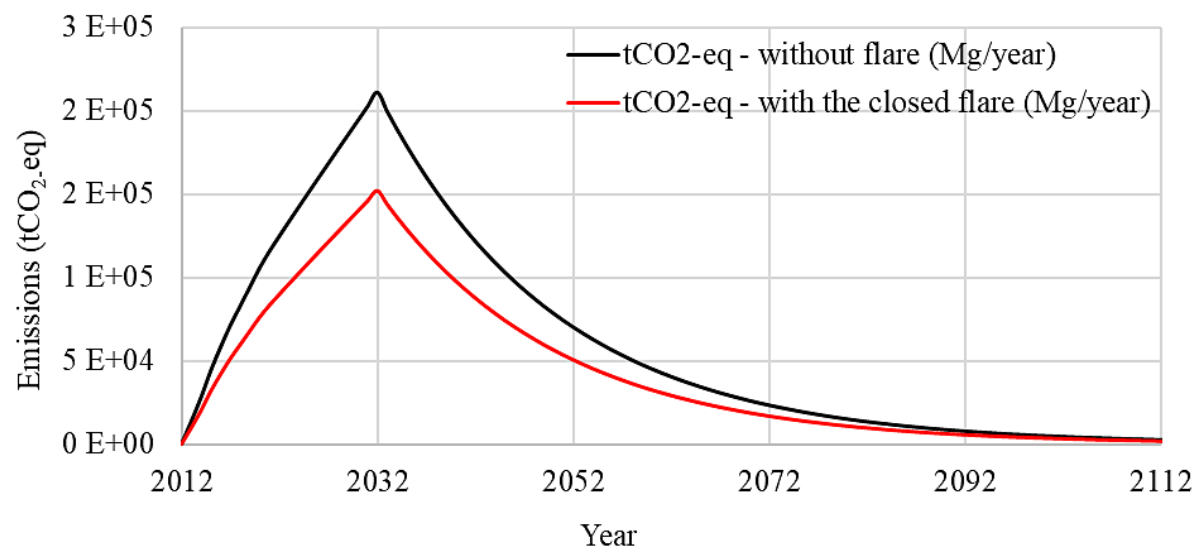

Figure 10. Annual estimate of the quantity of $\mathrm{CO}_{2}(\mathrm{Mg} / \mathrm{year})$ of Mohammedia-Benslimane landfill

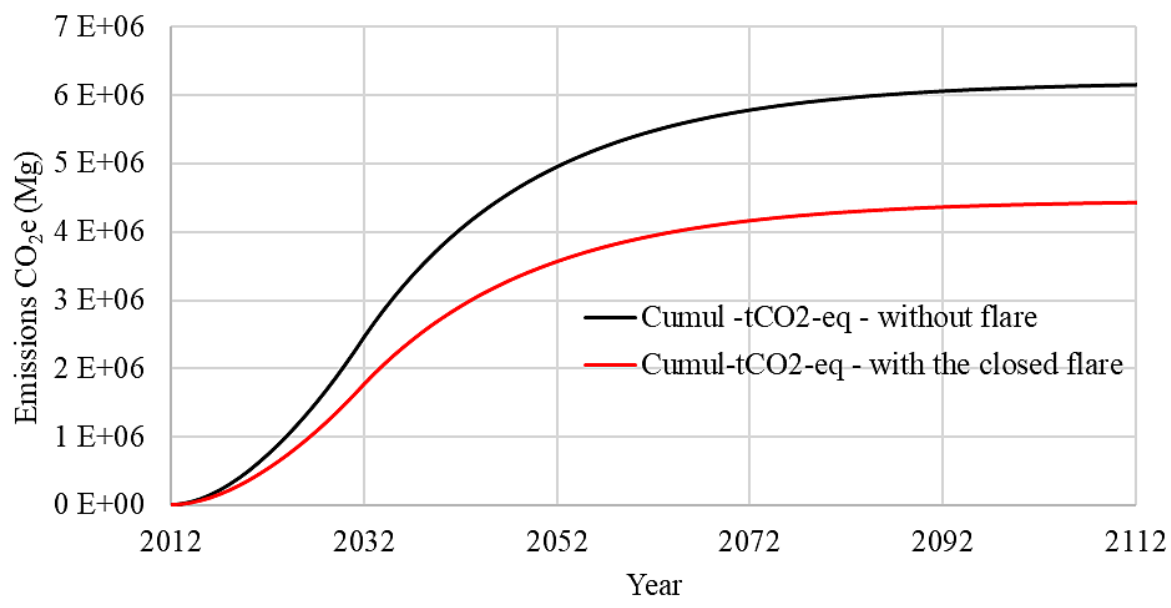

Figure 11. Cumulative sum chart of global warming potential of Mohammedia-Benslimane landfill

greenhouse gas mitigation. As the methane gas is considered as one of the major contributors for the global warming and also a source of green energy, it needs to be sequestered. According to the LandGEM model, the maximum methane production rate is $1.50 \mathrm{E}+07 \mathrm{~m}^{3} /$ year and is observed during the year 2032 for this controlled Landfill. The year 2032 correspond to the closure year of Mohammedia-Benslimane. The methane gases that will be recovered from the controlled landfill can be converted into energy. We have shown that the estimated electrical energy in this landfill was 35.2 GWh for the year 2032. Therefore, it can be concluded that the Mohammedia-Benslimane landfill is a source for energy production and can be used to move fossil fuels. With the flare system implemented in this controlled landfill of Mohammedia-Benslimane, it is possible to observe a $72 \%$ reduction in $\mathrm{CO}_{2}$ e emission. The total emission reductions achievable from the landfill gas recovery during the 20-year Period, 2012 through 2032, are $1.78 \mathrm{E}+06$ tons of $\mathrm{CO}_{2} \mathrm{e}$.
For the follow-up of this study, it appeared to us very interesting to study the impact of the gases formed at the time of the flaring of the biogas in this site on the potential of acidification, namely the sulfur dioxide $\left(\mathrm{SO}_{2}\right)$ and the hydrochloric acid $(\mathrm{HCl})$, and on the other hand to proceed to a desulfurization of the biogas of this site (by decreasing the quantity of hydrogen sulfide $\left(\mathrm{H}_{2} \mathrm{~S}\right)$ ) if a unit of production of electric energy will be installed locally for the next years.

\section{Acknowledgements}

We would like to thank Mr. M.C. Alaoui, Deputy Director of the ECOMED Group and Mr. S. Annouar, Director of Operations of the MohammediaBenslimane controlled landfill (ECOMED Group).

\section{REFERENCES}

1. Abbasi S.A. 2018. The myth and the reality of energy recovery from municipal solid waste. Energy, Sustainability and Society, 8(1), 2-15. 
2. Ayodele T.R., Ogunjuyigbe A.S.O., Alao Power M.A. 2017. Life cycle assessment of waste-to-energy (WtE) technologies for electricity generation using municipal solid waste in Nigeria. Applied Energy, 201, 200-2018.

3. Chofqi A., Younsi A., Lhadi E., Mania J., Mudry J., Veron A. 2004. Environmental impact of an urban landfill on a coastal aquifer (El Jadida, Morocco). Journal of African Earth Sciences, 39(3-5), 509-516.

4. Cudjoe D., Su Han M. 2021. Economic feasibility and environmental impact analysis of landfill gas to energy technology in African urban areas. Journal of Cleaner Production, 284, 125437.

5. Elmaghnougi I., Afilal Tribak A., Maatouki M. 2018. Assessment of leachates from uncontrolled landfill: Tangier case study. E3S Web of Conferences, 37, 4-13.

6. EPA USA. 2008. Background Information Document for Updating AP42 Section 2.4 for Estimating Emissions from Municipal Solid Waste Landfills. September (EPA/600/R-08-116), 249.

7. Fei F., Wena Z., De Clercqa D. 2019. Spatio-temporal estimation of landfill gas energy potential: A case study in China. Renewable and Sustainable Energy Reviews, 103(C), 217-226.

8. Haro K., Ouarma I., Sanogo O., Compaore A., Tubreoumya G.C., Nana B., Bere A., Koulidiati J. 2019. Assessment of the carbon footprint of a NonHazardous Waste Storage Facility (NWISH): Case of the waste treatment and recovery center (CTVD) in Polesgo (Ouagadougou). Journal de Physique de la SOAPHYS, 1(1), C19A5-1-C19A5-5. (in French)

9. Kumar A., Samadder S.R. 2017. A review on technological options of waste to energy for effective management of municipal solid waste. Waste Management, 69 , 407-422.
10. Lattanzi I.E., Prata Filho D.A., Quelhas O.L.G. 2019. Modeling of biogas generation by applying CDM methodology for greenhouse gas emission reduction: case of the MTR Santa Maria Madalena landfill, RJ, Brazil. Systems \& Management, 14(4), 483-491.

11. Naimi Y., Saghir M., Cherqaoui A., Chatre B. 2017. Energetic recovery of biomass in the region of $\mathrm{Ra}-$ bat, Morocco. International Journal of Hydrogen Energy, 42(2), 1396-1402.

12. Noor Z., Yusuf R, Abba A., Abu Hassan M., Mohd Din M. 2013. An overview for energy recovery from municipal solid wastes (MSW)in Malaysia scenario. Renewable and Sustainable Energy Reviews, 20, 378-384.

13. Park J., Tameda K., Higuchi S., Lee N. 2017. Estimation of the methane generation rate constant using a large-scale respirometer at a landfill site. Environmental Engineering Research, 22(4), 339-346.

14. Pillai J., Riverol C. 2018. Estimation of gas emission and derived electrical power generation from landfills. Trinidad and Tobago as study case. Sustainable Energy Technologies and Assessments, 29(October 2017), 139-146.

15. Plocoste T., Jacoby-Koaly S., Petit R., Roussas A. 2016. Estimation of Methane Emission from a Waste Dome in a Tropical Insular Area. International Journal of Waste Resources, 6(2), 1000211.

16. Saghir M., El Mahi Chbihi M., Tahiri M., Naimi Y. 2018. Estimated Production of Electrical Energy for the Controlled Landfill in Fez (Morocco) by the Land-GEM Model of US EPA. American Journal of Earth Science and Engineering, 1(2), 137-142

17. Tayyeba O., Olsson M., Brandt N. 2011. The best MSW treatment option by considering greenhouse gas emissions reduction: a case study in Georgia. Waste Management and Research, 29(8), 823-833. 